IJBPAS, September, 2021, 10(9): 3349-3358

ISSN: 2277-4998

International Journal of Biology, Pharmacy and Allied Seiences (IJBPAS)

'A Bridge Betuen Caboratory and Q pando'

WwW.ijbpas.com

\title{
LYCOPENE, RASPBERRY, GREEN TEA HERBAL FORMULATION MEDIATED SILVER NANOPARTICLES AND ITS CYTOTOXIC EFFECT
}

\section{MUKUNDH CHAITHANYA V ${ }^{1}$, UMA MAHESWARI. T. $\mathbf{N}^{2^{* *}}$ AND S RAJESHKUMAR ${ }^{3}$}

1: Saveetha Dental College and Hospitals, Saveetha Institute of Medical and Technical Sciences

(SIMATS), Saveetha University, Chennai, India

2: Head of Admin, Department of Oral Medicine and Radiology, Saveetha Dental College and Hospitals, Saveetha Institute of Medical and Technical Sciences (SIMATS), Saveetha University, Chennai, India

3: Associate Professor, Nano-biomedicine Lab, Department of Pharmacology, Saveetha Dental College and Hospitals, Saveetha Institute of Medical and Technical Sciences (SIMATS), Saveetha University,

Chennai, India

*Corresponding Author: Dr. Uma Maheswari.T.N: E Mail: umamaheswaritn@saveetha.com

Received 29 ${ }^{\text {th }}$ March 2021; Revised 27 ${ }^{\text {th }}$ April. 2021; Accepted 24 ${ }^{\text {th }}$ June 2021; Available online $1^{\text {st }}$ Sept. 2021

https://doi.org/10.31032/IJBPAS/2021/10.9.6212

ABSTRACT

Aim: Preparation of lycopene, raspberry, green tea and silver nano particle herbal formulation and assessing its cytotoxicity. Materials and methods: Extracts of $25 \%$ raspberry, $10 \%$ lycopene, green tea (95\% of polyphenols) and silver nanoparticles are subjected for Herbal formulation preparation, and is subjected to cytotoxicity testing, the formulation was prepared using carboxymethylcellulose, hydroxypropyl methyl cellulose, Carbopol, sodium chloride, and distilled water, Toxicity testing using brine shrimp lethality assay. Results: The maximum survival rate of brine shrimp at the highest dose of $80 \mu 1$ is 7 (out of 10) and at least concentration of $5 \mu \mathrm{l}$ all the 10 shrimp fishes survived in $24 \mathrm{hrs}$.Conclusion:the combination of lycopene, raspberry, green tea and silver nanoparticles have shown the least cytotoxic effect at various concentrations of herbal extracts.

Keywords: Lycopene, nanoparticle, cytotoxicity 


\section{INTRODUCTION}

Cytotoxicity screening is a method that is used to find that compounds that are present in the plants, this is done to find the effects of fibroblasts and keratinocytes in an invitro environment. [1, 2, 20-22]. Toxicity arises from the disruption of specific biochemical process or through the cytotoxical mediated process, the morphological shape, growth and reproduction of the cell can be observed $[3,4,23,36,37]$. The herbal extracts which are sold in the market are known to contain substances that may cause toxicity when used as medication, substances such as butanol present in the raspberry have showed the highest toxicity in compared to the othercompounds which are present in raspberry $[\mathbf{5}, \mathbf{6}, \mathbf{2 4}, \mathbf{2 5}, \mathbf{3 8}]$. The cytotoxicity assessment can be done by recording the apoptosis (programmed cell death) as this is an important parameter $[7,26,39,40]$.

\section{MATERIALS AND METHODS}

Herbal extracts containing Raspberry (25\%), Lycopene (10\%) and Green tea extract (95\% polyphenols) weighing 0.50 gm each (Figure 1), mixed with $100 \mathrm{~mL}$ distilled water. The extracts are boiled at $50^{\circ} \mathrm{C}$ for 1 hour which is mixed with $0.016 \mathrm{gm}$ of silver nano particles which is thoroughly stirred where a noticeablecolor change of fluid is seen (Figure 2), the fluid is then centrifuged at
$8000 \mathrm{rpm}$ post which the concentrated fluid is separated from supernatant fluid. (Figure 3). This herbal formulation is subjected to Cytotoxicity testing using the brine shrimp lethality assay. The brine shrimp fishes are administered to the herbal formulation containing silver nanoparticles taken in 5 dose levels $5 \mu \mathrm{l}, 10 \mu \mathrm{l}, 20 \mu \mathrm{l}, 40 \mu \mathrm{l}$ and $80 \mu \mathrm{l}$ and the live brine shrimp fishes are administered each of these wells and are observed for about 24 hours, the survival level is noted (Figure 4).

\section{RESULTS AND DISCUSSION}

The results of this study showed that at even at a highest dose of $80 \mu$ about 7 shrimp fishes have survived, while at the least levels of administration, at $5 \mu \mathrm{l}$, all the 10 shrimp fishes have survived in the period of 24 hours (Chart 1).

Rath et al (2009) has shown the lycopene in usually present at levels between $5 \%$ to $15 \%$ is commonly available at the market which is effectively used as a medicament which the same levels is used in our study wherein lycopene in concentrations of $10 \%$ is used ${ }^{(8,9)}$ Studies done by lee et al. (2016) the raspberry, mulberry showed the highest toxicity in the concentration of $200 \mu$ l with only $20 \%$ of cell viability), while in the current study the herbal formulation in the 
concentration of $80 \mu \mathrm{l}$ the highest toxicity can be seen, while the lowest is seen in concentration of $5 \mu$ l. [10, 11, 27, 28, 41] Studies done by Lao et al (2015) has shown the green tea at an high levels of $1000 \mu \mathrm{g} / \mathrm{ml}$ showed the cytotoxic effect, which in comparison with my study a similar result wherein maximum cytotoxic effect is seen at a higher dosage of $80 \mu \mathrm{l}$ which was similar. Other studies done by Weisberg et al. (2004) has shown that after period of 72 hours the cytotoxic activity has shown to be in the highest level, but in the current study in about 24 hours the cytotoxic effects can be observed $[12,13,29,30,31]$. The toxicity of silver nanoparticle is demonstrated in studies done by Enrique et al (2008) has shown that cytotoxic effects of silver along with copper is high at $500 \mathrm{~nm}$ in comparison with $\mathrm{AgNO}_{3}$ which is less toxic, but in contrast the current study showed only less cytoxicity, even at $80 \mu$ concentrations of herbal concentrations of silver nanoparticles have showed the less toxic effects, out of 10 brine shrimp fishes subjected to analysis almost 7 fishes have survived a viable period of 24 hours which proves that this combination of lycopene, raspberry and green tea along with combination of silver nanoparticles is less toxic $[14,15,32,33]$. While studies done by William et al (2019) has showed that the cytotoxicity of green tea based silver nanoparticles concentration was absolutely less (less than $0.1 \%$ ), initially at $50 \mathrm{ul}$ using MMT assay the cytotoxicity was nil and even at $100 \mu$ concentration the was less or nil [16, $17,34,35]$.

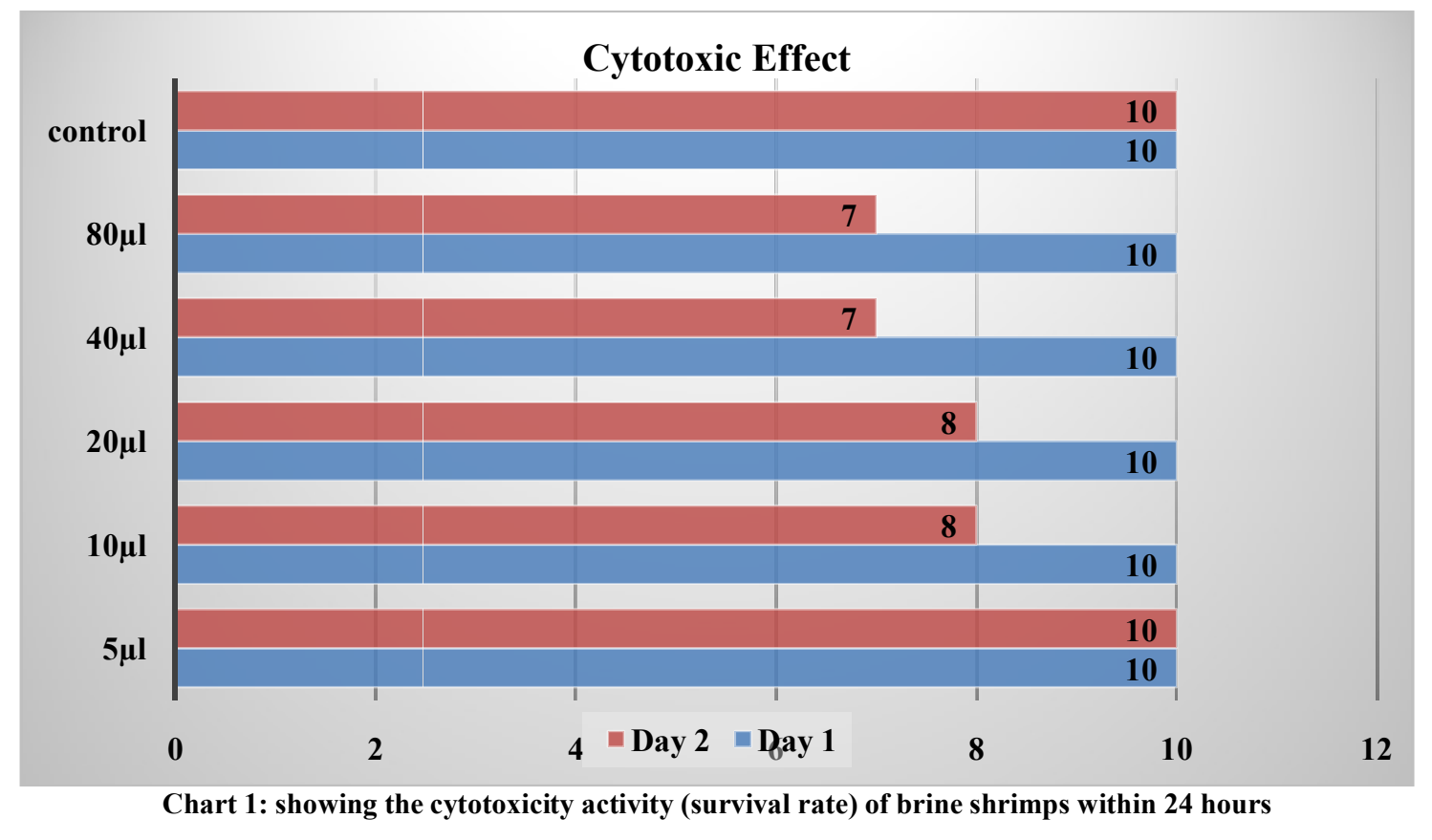

IJBPAS, September, 2021, 10(9) 


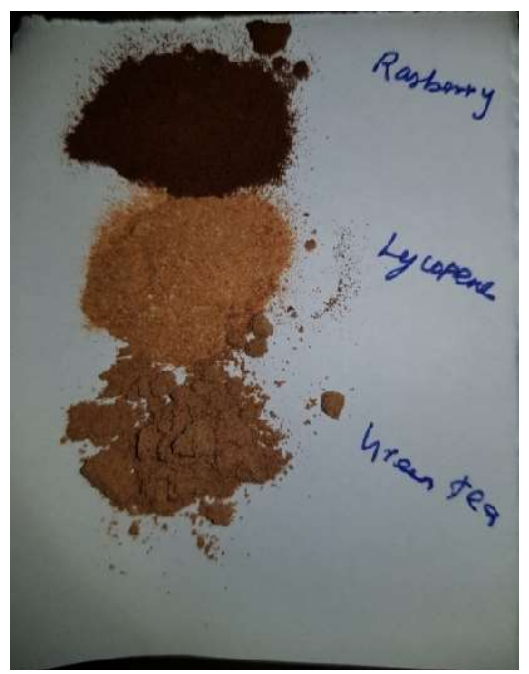

Figure 1: Extracts including raspberry, lycopene and green tea in $0.5 \mathrm{gm}$ concentration of each

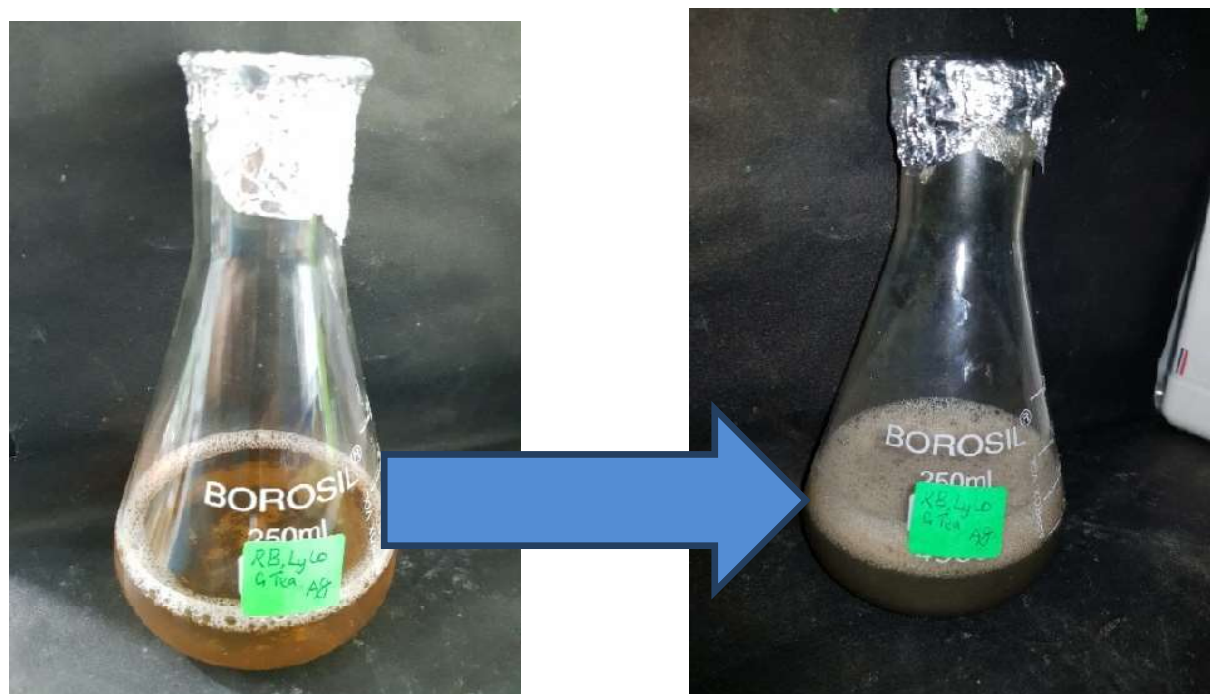

Figure 2: Addition of silver nanoparticles to the herbal formulation containing lycopene, raspberry and green tea, note the change in color of the formulation post titration

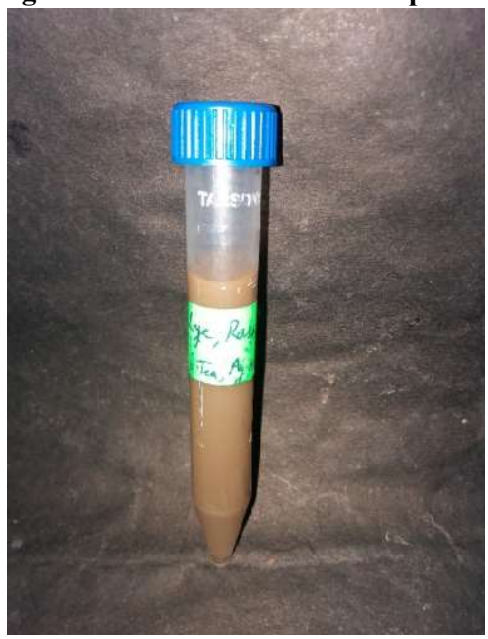

Figure 3: Concentrated herbal formulation post centrifugation under refrigitrated centrifugation machine under 8000rpm 


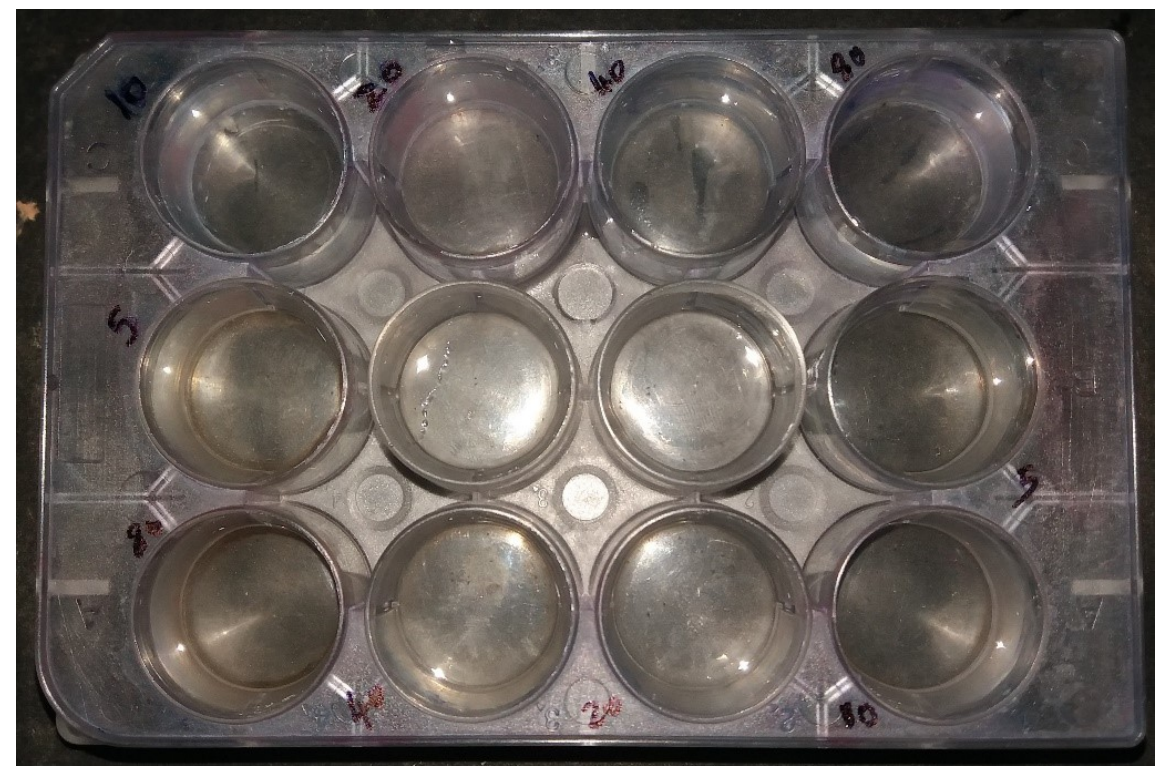

Figure 4: Showing well's containing brine shrimp fish along with various herbal formulation concentrations of $5 \mu \mathrm{l}, 10 \mu \mathrm{l}$

\section{REFERENCES}

[1] Lee D, Kang KS, Lee S, Cho EJ, Kim HY. Cytotoxic effects of strawberry, Korean raspberry, and mulberry extracts on human ovarian cancer A2780 cells. Preventive nutrition and food science. 2016 Dec; 21(4): 384.

[2] Ogbole OO, Segun PA, Adeniji AJ. In vitro cytotoxic activity of medicinal plants from Nigeria ethnomedicine on Rhabdomyosarcoma cancer cell line and HPLC analysis of active extracts. BMC complementary and alternative medicine. 2017 Dec; 17(1): 1-0.

[3] Pal A, Toppo FA, Chaurasiya PK, Singour PK, Pawar RS. In-vitro cytotoxicity study of methanolic fraction from Ajuga Bracteosa wall ex. benth on MCF-7 breast adenocarcinoma and hep-2 larynx carcinoma cell lines. Pharmacognosy research. 2014 Jan; 6(1): 87.

[4] de Mesquita ML, de Paula JE, Pessoa C, de Moraes MO, Costa-Lotufo LV, Grougnet R, Michel S, Tillequin F, Espindola LS. Cytotoxic activity of Brazilian Cerrado plants used in traditional medicine against cancer cell lines. Journal of ethnopharmacology. 2009 Jun 25; 123(3): 439-45.

[5] Ruffa MJ, Ferraro G, Wagner ML, Calcagno ML, Campos RH, Cavallaro L. Cytotoxic effect of Argentine medicinal plant extracts on human hepatocellular carcinoma cell 
line. Journal of ethnopharmacology. 2002 Mar 1; 79(3): 335-9.

[6] Lao W, Tan Y, Jin X, Xiao L, Kim JJ, $\mathrm{Qu}$ X. Comparison of cytotoxicity and the anti-adipogenic effect of green tea polyphenols with epigallocatechin-3-gallate in 3T3-L1 preadipocytes. The American journal of Chinese medicine. 2015 Sep 14; 43(06): 1177-90.

[7] Weisburg JH, Weissman DB, Sedaghat T, Babich H. In vitro cytotoxicity of epigallocatechin gallate and tea extracts to cancerous and normal cells from the human oral cavity. Basic \& clinical pharmacology \& toxicology. 2004 Oct; 95(4): 191-200.

[8] Levard C, Hotze EM, Lowry GV, Brown Jr GE. Environmental transformations of silver nanoparticles: impact on stability and toxicity. Environmental science \& technology. 2012 Jul., 3; 46(13): 6900-14.

[9] Prabhu S, Poulose EK. Silver nanoparticles: mechanism of antimicrobial action, synthesis, medical applications, and toxicity effects. International nano letters. 2012 Dec; 2(1): 1-0.
[10] Navarro E, Piccapietra F, Wagner B, Marconi F, Kaegi R, Odzak N, Sigg L, Behra R. Toxicity of silver nanoparticles to Chlamydomonas reinhardtii. Environmental science \& technology. 2008 Dec 1; 42(23): 8959-64.

[11] Zapata Vahos IC, Villacorta V, Maldonado Celis ME, Castro Restrepo D, Rojano BA. Antioxidant and cytotoxic activity of black and green tea from Vaccinium meridionale Swartz leaves.

[12] Ziemlewska A, Zagórska-Dziok M, Nizioł-Łukaszewska Z. Assessment of cytotoxicity and antioxidant properties of berry leaves as byproducts with potential application in cosmetic and pharmaceutical products. Scientific Reports. 2021 Feb 5; 11(1): 1-4.

[13] Rath S, Olempska-Beer Z, Kuznesof PM. Lycopene extract from tomato Chemical and Technical Assessment (CTA). Lycored Natural Products Industries Ltd, Israel. 2009.

[14] Beer C, Foldbjerg R, Hayashi Y, Sutherland DS, Autrup H. Toxicity of silver nanoparticlesnanoparticle or silver ion? 
Toxicology letters. 2012 Feb 5; 208(3): 286-92

[15] Devi AU, Khanam S. Preparation and Characterization of Herbal Nanoformulation Containing Andrographis Paniculata Extract.

[16] Dongarwar A, Nimbekar T, Parshuramkar T, Indurwade $\mathrm{N}$. Preparation and Evaluation of Herbal Formulation Using Natural Extract. Chemical Methodologies. 2019 Jul 1; 3(4): 451-6.

[17] Ashidi JS, Houghton PJ, Hylands PJ, Efferth T. Ethnobotanical survey and cytotoxicity testing of plants of South-western Nigeria used to treat cancer, with isolation of cytotoxic constituents from Cajanus cajan Millsp. leaves. Journal of Ethnopharmacology. 2010 Mar 24; 128(2): 501-12.

[18] Szymanowska U, Baraniak B, Bogucka-Kocka A. Antioxidant, anti-inflammatory, and postulated cytotoxic activity of phenolic and anthocyanin-rich fractions from polana raspberry (Rubus idaeus L.) fruit and juice-In vitro study. Molecules. 2018 Jul; 23(7): 1812.

[19] Rolim WR, Pelegrino MT, de Araújo Lima B, Ferraz LS, Costa
FN, Bernardes JS, Rodigues T, Brocchi M, Seabra AB. Green tea extract mediated biogenic synthesis of silver nanoparticles: characterization, cytotoxicity evaluation and antibacterial activity. Applied Surface Science. 2019 Jan 1; 463: 66-74.

[20] S. Rajeshkumar, S. Venkat Kumar, Arunachalam Ramaiah, Happy Agarwal, T. Lakshmi, Selvaraj Mohana Roopan Biosynthesis of zinc oxide nanoparticles using Mangifera indica leaves and evaluation of their antioxidant and cytotoxic properties in lung cancer (A549) Cells Enzyme and Microbial Technology 117 (2018): 91-95.

[21] Vairavel, M., Devaraj, E. \& Shanmugam Rajeshkumar. An ecofriendly synthesis of Enterococcus sp.-mediated gold nanoparticle induces cytotoxicity in human colorectal cancer cells. Environ Sci Pollut Res., (2020) 27: 8166-8175.

[22] Swapna Sreenivasagan, Aravind Kumar Subramanian and S. Rajeshkumar (2020). Assessment of antimicrobial effects and cytotoxic effect of green mediated silver nanoparticles and its coating onto 
mini-implants. Ann. Phytomed., 9(1): 207-212.

[23] Mohapatra S, Rajeshkumar S, Leelavathi L, et al. Assessment of cytotoxicity, anti-inflammatory and antioxidant activity of zinc oxide nanoparticles synthesized using clove and cinnamon formulation-an in-vitro study. J. Evolution Med. Dent. Sci. 2020; 9(25): 1859-1864, DOI: $10.14260 /$ jemds/2020/405

[24] Aparna J, \& Rajeshkumar S. (2020). Cytotoxic and Antioxidant Activity of Zinc Oxide Nanoparticles Synthesised Using Maranta Arundinacea Root Extract. International Journal of Research in Pharmaceutical Sciences, 11(3), 4372-4377.

https://doi.org/10.26452/ijrps.v11i3. $\underline{2655}$

[25] Nandhini JT, Ezhilarasan D, Rajeshkumar S. An ecofriendly synthesized gold nanoparticles induces cytotoxicity via apoptosis in HepG2 cells. Environmental Toxicology. 2020; 1-9. https://doi.org/10.1002/ tox.23007.

[26] Karthik, V., Arivarasu, L., \& Rajeshkumar, S. (2020). Hyaluronic Acid Mediated Zinc Nanoparticles against Oral Pathogens and Its Cytotoxic Potential. Journal of Pharmaceutical Research International, 32(19), 113-117. https://doi.org/10.9734/jpri/2020/v3 $2 \mathrm{i} 1930716$

[27] Lakshme, P. S. T., S, P., Jeevitha, M., \& Rajeshkumar, S. (2020). Evaluation of Antioxidant and Cytotoxic Effect of Selenium Nanoparticles Synthesised Using Capparis decidua. Journal of Pharmaceutical Research International, 32(19), 60-66. https://doi.org/10.9734/jpri/2020/v3 $\underline{2 \mathrm{i} 1930709}$

[28] Shree, M. K., Arivarasu, L., \& Rajeshkumar, S. (2020). Cytotoxicity and Antimicrobial Activity of Chromium Picolinate Mediated Zinc Oxide Nanoparticle. Journal of Pharmaceutical Research International, 32(20), 28-32.

https://doi.org/10.9734/jpri/2020/v3 $\underline{2 \mathrm{i} 2030726}$

[29] Ananya, R., Roy, A., Rajeshkumar, S., \& Lakshmi, T. (2020). Antioxidant And Cytotoxic Effects Of Silver Nanoparticles Synthesised Using Hing Oil. Plant Cell 
Biotechnology and Molecular

Biology, 21(27-28), 1-8.

[30] Thirumagal, K., Rajeshkumar, S., \& Roy, A. (2020). In Vitro Cytotoxic Effect Of Zirconium Oxide Nanoparticle And Its Antibacterial Activity Against Oral Pathogens. Plant Cell Biotechnology And Molecular Biology, 21(27-28), 2836

[31] Dhivyadharshini, J., Arivarasu, L., \& Kumar, S. R. (2020). Antimicrobial And Cytotoxic Activity Of Adhatoda Vasica Mediated Copper Nano Particle. Plant Cell Biotechnology And Molecular Biology, 21(29-30), 1-7

[32] Kandhan, T. S., Rajasekar, A., \& Rajeshkumar, S. (2020). Grape Seed Aqua Alcoholic Extract Preparation And Its Antioxidant, Antimicrobial And Cytotoxic Effect - An In Vitro Study. Plant Cell Biotechnology And Molecular Biology, 21(31-32), $18-26$

[33] Kaviya, N. E., Roy, A., Rajeshkumar, S., \& Lakshmi, T. (2020). Cytotoxicity Study Of Copper Oxide Nanoparticle Mediated Through Tamarind Extract. Plant Cell Biotechnology
And Molecular Biology, 21(31-32), 36-43.

[34] Yuvashree, C. S., Rajasekar, A., \& Rajeshkumar, S. (2020). Cytotoxic Effect Of Titanium Dioxide Nanoparticles Synthesized Using Grape Seed Extract: An In Vitro Study. Plant Cell Biotechnology And Molecular Biology, 21 (31-32), $120-126$

[35] Francis T, Rajeshkumar S, Roy A, Lakshmi T. Anti-inflammatory and Cytotoxic Effect of Arrow Root Mediated Selenium Nanoparticles. Pharmacogn J. 2020; 12(6): 1363-7. DOI : $10.5530 /$ pj.2020.12.188

[36] Jochebed RS, Roy A, Shanmugam $\mathrm{R}$, et al. Preparation and characterization of cinnamon oil mediated gold nanoparticles synthesis and evaluation of its cytotoxicity using brine shrimp lethality assay. J Evolution Med Dent Sci 2020; 9(39): 2894- 2897, DOI: $10.14260 /$ jemds/2020/633.

[37] Nasim I, Rajeshkumar s, Vishnupriya VP (2020) Cytotoxicity and anti-microbial analysis of silver and graphene 
oxide bio nanoparticles

Bioinformation 16(11): 831-836

[38] Begum, A., Jeevitha, M., Preetha, S., \& Rajeshkumar, S. (2020). Cytotoxicity of Iron Nanoparticles Synthesized Using Dried Ginger. Journal of Pharmaceutical Research International, 32(25), 112-118. https://doi.org/10.9734/jpri/2020/v3 $\underline{2 \mathrm{i} 2530829}$

[39] Shankar, S. B., Arivarasu, L., \& Rajeshkumar, S. (2020). Biosynthesis of Hydroxy Citric Acid Mediated Zinc Nanoparticles and Its Antioxidant and Cytotoxic Activity. Journal of Pharmaceutical Research International, 32(26), 108-112. https://doi.org/10.9734/jpri/2020/v3 $\underline{2 \mathrm{i} 2630845}$

[40] Shanmugam R, Balusamy SR, Kumar V, Menon S, Lakshmi T, Perumalsamy H. Biosynthesis of gold nanoparticles using marine microbe (Vibrio alginolyticus) and its anticancer and antioxidant analysis. Journal of King Saud University-Science. 2020 Dec 4:101260.

[41] Rajeshkumar S, Malarkodi C, Al Farraj DA, Elshikh MS, Roopan SM. Employing sulphated polysaccharide (fucoidan) as medium for gold nanoparticles preparation and its anticancer study against HepG2 cell lines. Materials Today Communications. 2020 Dec 17:101975. 